\title{
THE NEED OF MUSLIM FLOATING MARKET FOR BANK SYARIAH \\ A Case Study of the Member of Pengajian Bisnis al-Kautsar NU in Special District of Yogyakarta
}

\author{
By: M. Roem Syibly ${ }^{*}$
}

\section{Abstract}

Entrepreneurs of $N U$, engaged in the al-Kautsar religious gathering, can be deemed as having good education and structural position either as a member or an organizer. They declare that NU institutionally gives a big contribution to their business. Their companies are generally home-industries in which they themselves pay the capital. Though the profit is less than IDR 5,000,000, they are aware of developing their industries. Their participation in the Islamic organization, NU, does not mean that they do not choose the conventional banking system, not the shariah one. Their choice is based upon a consideration which banking system is more beneficial for them. To put simply, it can be said that they will be enthusiastic and interested in utilizing the services of shariah-banking system if they could get more benefits. However, they prefer interest system than profit-sharing system. They consider both systems as being at the same position and regard interest as religiously acceptable. Therefore, they believe that conventional banking system is allowed in Islam. Though having preference to conventional banking system, they still possibly utilize shariahbanking system as long as it can give more facilities and benefits and confess that shariah-banking system is in line with their religious doctrines.

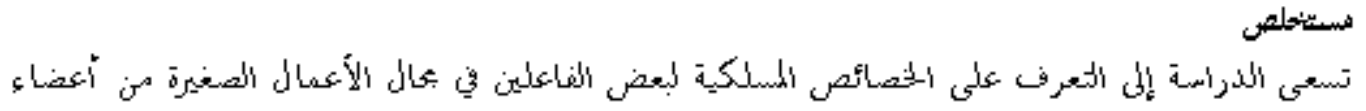

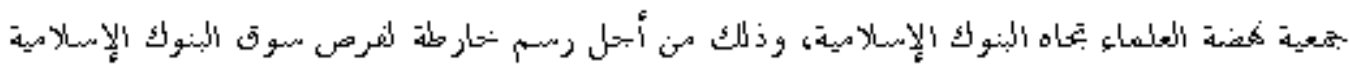

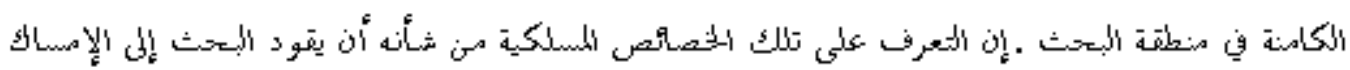

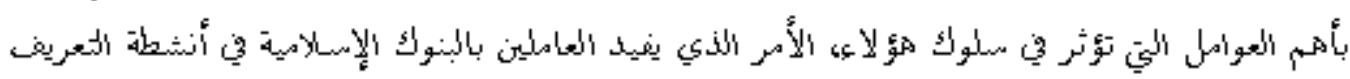

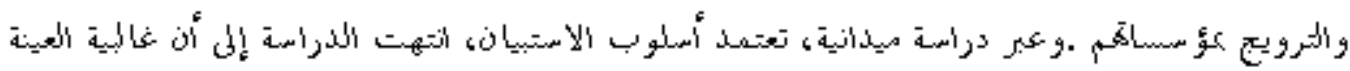

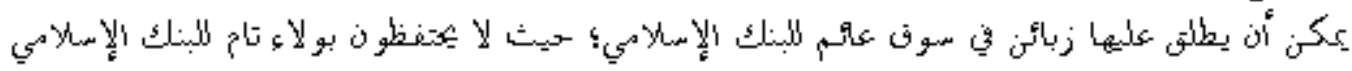

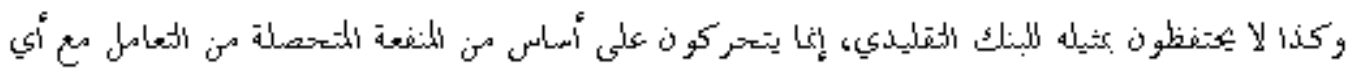




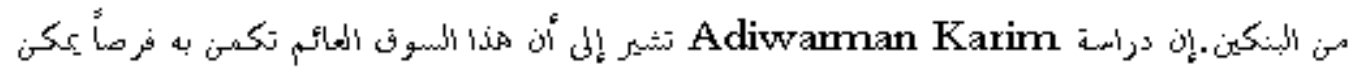

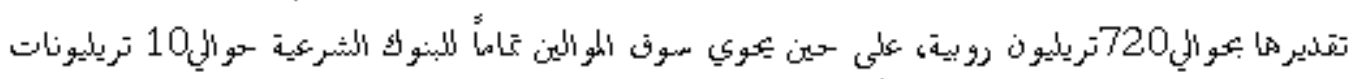

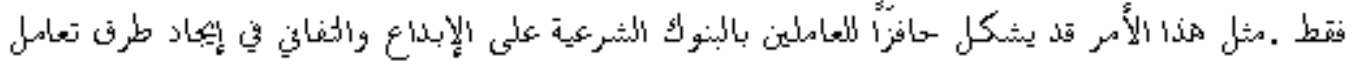

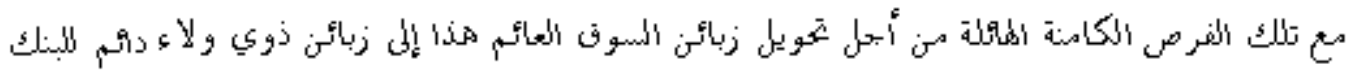

$$
\begin{aligned}
& \text { الشريكي }
\end{aligned}
$$

Keywords: floating market, entrepreneur of NU, syariah bank.

\section{A. Introduction}

Adiwarman Karim found that based on market potency there are three market groups: syariah committed market, ${ }^{1}$ floating market which is less committed to a certain banking system, ${ }^{2}$ and conventional market. Syariah banking tends to play in syariah committed markets. Based on Karim's research,

To survive and extend their domain, syariah banks should be targeted at floating markets whose potency reaches Rp 720 billion. ${ }^{4}$ As a result, this business potency has stimulated banking industry actors to compete dominating markets. Markets can be divided into floating customers, both individuals and corporations, that need normal services; and special customers who need more private services. ${ }^{5}$ It is these floating customers, with their financial potency, who should be the target of Bank Syariah. ${ }^{6}$

Members of the NU (Nahdlatul Ulama), commonly identified as traditional Muslims, are organizationally free to choose their preferred banks in Indonesia, either conventional Bank or Bank Syariah. This means that they are part of the floating markets which are also potential markets for Bank Syariah. In addition, their attitude towards banking interest is heavily dependent on their own understanding on it. In a number of its muktamar, the NU reached three opinions on banking interest including haram (unlawful), shubhah (no clarity between the lawful and the unlawful) and halal (lawful). Thus, people preserve to determine what they adhere to. ${ }^{7}$ These were 
affirmed by Lajnah Bahtsu al-Masâil Nadlatul Ulama, ${ }^{8}$ that the NU lets its members choose what they want. ${ }^{9}$

This research is aimed at understanding characteristics and attitudes of the NU corporations towards Bank Syariah so as to figure out the potency of the NU entrepreneurs in Yogyakarta. In addition, it is also aimed at identifying dominant factors influencing the NU entrepreneurs in choosing Bank Syariah.

\section{B. Research Method}

This is a field research, ${ }^{10}$ with a special focus on members of Islamic gathering (pengajian) al-Kautsar, The NU, in Daerah Istimewa (Special Region of) Yogyakarta. ${ }^{11}$ I have taken $20 \%$ samples (47 respondents) of 229 NU entrepreneurs. Here I have applied two models of sample. One is convenient sample, a sample taken unintentionally where persons included in the population met by the researcher and ${ }^{12}$ and random sampling.

In getting data, I have used a questionnaire method; since it is a simple way to collect data flexibly and easily. ${ }^{13}$ The questionnaires were shared to members of Pengajian al-Kautsar for four meetings with 29 samples and the remaining 18 given randomly to respondents in their homes or offices. The collected data are then analysed by using the descriptive and regressive-logistic models. Descriptive analysis is used to answer how NU entrepreneurs' characteristics and how their attitude towards Bank Syariah are. Regressive-logistic is a statistic method to understand mathematic relation between a dependent variable and one or more independent variables. ${ }^{14}$ The main aim of this analysis is to predict probability of an event based on predictive values and to classify the subject matter based the threshold of probabilities. ${ }^{15}$

\section{Economic Movements of the $\mathrm{NU}$}

The establishment of the Nahdlatul Ulama (NU) in 1926 was preceded by the establishment of three organisations. The first was the Nahdlatul Tujjar 1918 which 
worked in economic sectors. Taswiru al-Afkar, established in1922, was concerned with science and culture. Nahdlatu al-Watan, established in1924, was concerned with politics through education. These three organisations became bases of the establishment of the NU. Seen from this, there are three pillars of the NU organisation, including mass-oriented economy, socio-cultural and intellectual realms; and national horizon. ${ }^{16}$

Nahdlatul al-Tujjâr was the name of Syirkah al-Inân, a trading system in the form of cooperative. ${ }^{17}$ This organisation was headed by K.H. Hasyim Asy'ari, while Abdul Wahab became a managing director. Its shared stock and capital was f. 1.125,-, paid by 45 individual members, each f.24,-. There is no further information on this cooperative except the certificate of its establishment. ${ }^{18}$ However, this is enough to say that some ten years before the establishment of the NU there had been an attempt among pesantren circles to make cooperation, regardless of its being local and not yet well arranged. ${ }^{19}$

The establishment of Nahdlatul al-Tujjâr was much more aimed at stimulating the care of boemi poetra about the decline of the nation as could be seen from the scarcity of students, the weakness of (social) ties and some of them had become free so that even (they) could not perform congregation prayers..$^{20}$ In 1930 an endowment association called Lajnah Waqfiyyah was established. Seven years after, it was changed into Waqfiyyah Nahdlatu al-'Ulamâ. The rise and decline of economic enterprises of the NU show that the economic ethos of its members is weak and often taken for granted by themselves. ${ }^{21}$ So, it becomes clear that from its economic enterprises the NU has been very concerned about the welfare of umma.

In this regard, two points should be noted. First of all is that Nahdlatu al-Tujjâr was the embryo organisation of the NU. ${ }^{22}$ Second is the NU's return to its initial struggle in 1926 called 'Khittah' ${ }^{23}$ as decided in its 27th Muktamar, 1984, held in Situbondo East Java, and reaffirmed in the 28th Muktamar held in Krapyak Yogyakarta in 1989. It becomes clear that the NU has long attempted to improve the 
life quality and welfare of its members through social and economic programmes and enterprises. ${ }^{24}$

In the 13th Muktamar 1935, the NU took the initiative of 'Gerakan Pembangunan Ekonomi' (Economische Mobilisatie or Economic Development Movement) among its members. The movement then was realised, among others, through lailatu al-ijmâ' (Gathering Night) forum conducted in its branches. ${ }^{25}$ in addition, a various number of cooperatives were established. In this Muktamar, KH. Mahfudz Sidiq put forward his idea on Mabâdi Khaira Umma (Principles of the Best Community), among which the principle as-sidqu al-amânah wa al-wafâ bi al-'ahdi (honesty, trustworthy, fulfilment of promises) and at-ta' $\hat{w} w u n$ (cooperation) became ethical norms for economic enterprises. These attempts to improve economic condition of its members were interrupted by World War II. Political preoccupation of its leaders became such salient until the idea of returning to the spirit of the khittah 1926 came up. ${ }^{26}$

By then, the NU paid much of its attention to the development of education and Islamic promulgation. In addition, it focused on new programmes of social and economic transformation. Therefore the NU became a kind of Non-Government Organisation development institute (LPSM).

The NU tried to improve community life through pesantren (traditional Islamic boarding school) as its main base of members. It had made a cooperation with Institute for Research, Education, Information, Economy and Social (LP3ES). In 1983, members of the NU established an NGO called Perhimpunan Pengembangan Pesantren dan Masyarakat (P3M).

Munas 1983 recommended the improvement of hajj (Islamic pilgrimage) facilities, monitoring food and beverages, counselling for new converts (mu'allaf), clean water providing. To realise this, the NU established Lembaga Kajian dan Pengembangan Sumber Daya Manusia (Lakpesdam). After Muktamar Situbondo, East Java, Lakpesdam organised a programme unit called Lembaga Kemaslahatan Keluarga Nadlatul Ulama (LKK-NU). After Muktamar Krapyak, the NU initiated the 
establishment of Bank Perkreditan Rakyat (BPR) providing loan for small entrepreneurs. ${ }^{27}$ In 1990, the NU took an important step in economic sectors. In cooperation with Bank Summa, Central Board of the NU established Bank Perkreditan Rakyat Nusumma. Unfortunately, only a year after its establishment, the bank collapsed.

The concern of the NU with economy is very salient. It has Lembaga Perekonomian NU (LPNU) in 24 regions and 207 branches throughout Indonesia. It also has Lembaga Pengembangan Pertanian NU (LP2NU) in 19 regions and 140 branches. In addition, it has Induk Koperasi Pesantren (Inkopotren), Lembaga Pengembangan Tenaga Kerja NU (LPTKNU), and Sarikat Buruh Muslimin Indonesia (Sarbumusi). However, compared to other sectors such as intellectual and politics, economic and social empowerment is a little bit less developed. ${ }^{28}$

As seen above, historically the NU has a high concern with economic sectors. However, most of its members are still under poverty. ${ }^{29}$ In other word, poverty is still the main problem of the NU members which comprise farmers, fishermen, small traders, and so on. ${ }^{30}$ As stated by the chairman of PBNU, KH Hasyim Muzadi, most of the NU members live in underdeveloped regions. ${ }^{31}$ This fact shows that economic concepts offered by the NU are still not systematically formulated.

In DIY, members of the NU established Majlis al-Tujjar and Pengajian alKautsar which are concerned with economy. Majelis at-Tujjar was established by Lembaga Perekonomian Nahdlatul Ulama (LPNU), PW-NU DIY, to enhance the economic independency of the NU members. According to its head, Mardiyanto, this is an attempt to follow the footsteps of the founding fathers of the $\mathrm{NU}$, such as $\mathrm{KH}$ Hasyim Asy'ari, KH Wahab Chasbullah and KH Bisri Sansuri. These figures started their struggles with economic development through Nahdlatu al-Tujjâr in 1918. Kiai Hasyim was the head, Kiai Wahab was a programme manager, and Kiai Bisri was treasurer. Majelis At-Tujjar involves experts in business and business actors. It also opens wide business access for its members. In its first gathering, it featured a speaker which specialised in motivating business beginners to develop their 
enterprises. ${ }^{32}$ Pengajian al-Kautsar is an independent legal organisation serving as a medium of economic empowerment for NU members. Its establishment is aimed at improving their economic life. ${ }^{33}$ According to official data of the NU DIY, there are 229 NU entrepreneurs.

\section{NU's Attitude towards Bank Interest}

Bank interest has become a debated issue since the second Muktamar held in Surabaya, 9-11 October $1927^{34}$ which enlisted three opinions on the issue: haram, halal and shubhat. The Muktamar declared pawn (gadai) interest as forbidden (haram) for carefulness. This was based on al-Asybâh wa an-Nazâir and I'ânah atTalibîn, vol. $3 / 56$ bab al-qard. ${ }^{35}$ This decree then became a basis for the 12th Muktamar in Malang, 20-24 Juni $1937^{36}$ to declare the bank interest as haram as it was equal to pawn interest. The 14th Muktamar in Magelang, 15-21 July $1939^{37}$ decided a legal status of cooperative interest slightly different from before. In this Muktamar, the issue was connected with whether or not transaction happened, written or spoken. In the great Conference of Syuriah NU, Surabaya, 19 March 1957, ${ }^{38}$ it was restated that both bank interest and pawn interest were forbidden. This decision was based on I'ânah at-Talibîn, vol. 3/20: ${ }^{39}$, Kitab at-Tuhfah vol. 2/24, ${ }^{40}$ and I'ânah atTalibîn, vol. 3/56.

Then in the 25th Muktamar, in Surabaya, 20-25 December 1971,41 the NU reaffirmed the unlawfulness of deposite interest for carefulness. This decision referred to Congress/Muktamar II 1927 and XII 1937 which declared the same.

In its Munas Alim Ulama, Cilacap, 15-18 November $1987^{42}$ the NU decided that administrative fee for loaners of cooperatives was similar to the unlawful interest. This was based on a hadith (the Prophet' saying): "every load which attracts interest is riba."

The issue of bank interest reached its peak in the Munas Alim Ulama in Bandar Lampung, 21-25 June 1992. In this Munas, the official method (manhaji) was 
decided in Lajnah Bahtsu al-Masâil. The method was for the first time applied to respond to the issue as follows:

1. It was equated with riba, so it was haram.

2. It was not equated with riba, so it was permitted (mubah).

3. It was shubhat (it was not identical with haram).

\section{E. Research Findings}

\section{Characteristics of Respondents}

In general, the comparative ratio between the NU officials and common members who are involved in business is $51 \%$ and $48.9 \%$. Most respondents are still active in the organisational activities of NU. In addition to that, they consider that so far the NU has contributed to the improvement of enterprises in terms of cooperation, proving information, training for business, mediating with banks. This profile shows that the NU organisation still functions significantly in encouraging the development of its members' business. From 47 respondents, $72.3 \%$ of them graduated from universities, undergraduates, postgraduates or doctorates. This shows that they who are involved in business are well-educated. $74.5 \%$ of their enterprises are home industries, and only $8.5 \%$ are firms. From home industries, $68.1 \%$ of its members have income under five million per month, and $25.6 \%$ between 6-10 million per month. There are only three respondents with income up to more than 11 million per month. They are the owners of limited companies.

On their capital, small enterprises commonly need a small capital so that they can afford it by themselves. Only $36.2 \%$ respondents take the advantage of banking services. $61.7 \%$ of them use their income to create new enterprises. To get capitals, $80.8 \%$ of them take the advantage of the services of conventional banks, while only $12.8 \%$ use the services of Bank Syariah. And the rest take the advantage of cooperative services. This finding shows that NU community give 
much of their trust to conventional banks more than Bank Syariah. Only few use the services of cooperatives. This is strange because cooperatives are the initial enterprises the NU ever made historically.

2. The Attitude of NU Entrepreneurs towards Bank Syariah

Respondents' choice of the preferred banks is tightly related to the interest they might take. $83 \%$ respondents pointed preferred banks, and only one respondent timidly agreed on. In general respondents chose the services of conventional banks. However, they still thought that if bank syariah give much more interest and better facilities, they will follow it. $82.9 \%$ potentially change to bank syariah, and $4.3 \%$ decided to remain with conventional banks. Such data show that their key motif to choose certain banks is interest. Taking this into consideration, Bank Syariah should be able to convince NU entrepreneurs that they would really take much advantage from any transaction in Bank Syariah more than in conventional banks. What they want from the service of Bank Syariah covers payment products and saving which its comparative ratio is $68.1 \%$ and $31.9 \%$. Their knowledge of Bank Syariah is much taken from mass media information, and only few who take from educational processes. Their responses to Bank Syariah vary. In general, $82.9 \%$ respondents believe that Bank Syariah is in accordance with Islamic teaching. Although some know the conformity of Bank Syariah with Islamic teaching, they are much more interested in interest they may get. The data above are important for Bank Syariah to expand its customers. It should take use of mass media, electronic as well as printed, to promote its products.

They view that transactions in Bank Syariah is relatively easy. 80.8\% respondents have known about Bank Syariah products. Even $47.8 \%$ of them know more than three products of Bank Syariah: wadiah, mudlârabah and murâbahah and others. Only one respondent knows nothing about the products of Bank Syariah. Although many know about Bank Syariah, they are actually foreign with 
it. 85.1\% respondents stated that they felt it difficult to understand the products of Bank Syariah, and only $14.9 \%$ of them do understand them. They are much more familiar with terms used in conventional banks. This means that even though they know the products but do not really understand them. For them, its services are still not satisfying enough. $85.1 \%$ respondents feel so, and only few do not.

This finding shows that the reason the respondents are still convenient with conventional banks is that they feel unsatisfied with Bank Syariah's services. ${ }^{44}$ However, it is interesting that $95.7 \%$ respondents still wish to get more information about Bank Syariah. This is a good opportunity for Bank Syariah to provide business actors of NU members in DIY with more information and satisfying services..$^{45}$ The little number of branches of Bank Syariah seem also to be the reason to choose or not. $74.5 \%$ respondents stated that they feel hard to find branches of Bank Syariah in their respective regions.

In general, some consider banking interest subhat and some other halal. Only the remaining $19.2 \%$ respondents regard it haram. This means that most NU members consider that banking interest is permitted in Islam. This attitude does not contradict the organization attitude which leaves it to its members. In this regard there is no distinction between Bank Syariah and conventional banks.

After describing the data above, let me make a regressive-logistic analysis as follows:

a. First is education, with coefficient $=1,232$. Sign positive shows that the higher a businessman got education level, much more he does not agree with banking interest system. Instead, they prefer profit sharing. Value sig $(p)=0,103>0,05$. It can be said that the level of education will not effect on the choice of profit sharing system more than interest system. Second is income, with coefficient = 1,564. Sign negative means that the higher income they get, the more possible they choose interest system rather than profit sharing. Value sig $(p)=0,076>$ 0,05 , it can be said that the high amount of income does not effect on variables of choice of profit sharing system more than interest system. Third is legal status of 
banking interest. With coefficients $=1,835$. Sign positive means that the higher score they consider banking interest haram, the more possible they choose profit sharing system rather than interest system. Value $\operatorname{sig}(p)=0,002<0,05$. It can be said that the opinion on the forbidden status of banking interest effects significantly on choosing profit sharing.

b. First is education, with coefficient $=1,899$. Sign positive means that the higher respondents' education level is, the more saliently different Bank Syariah and conventional banks are. In other words, the higher education they have, the more possible they disagree on Bank Syariah as well as conventional banks. Sig $(\mathrm{p})=$ $0,027<0,05$. It can be said that education effects on the opinion that Bank Syariah ada conventional banks are different. Second is income, with coefficient $=-0,541$, sign negative means that the higher income they get, the more they think that Bank Syariah and conventional banks are the same. Or in other words, the higher income they have, the more they agree that both Bank Syariah and conventional banks are the same. Sig $(p)=0,404>0,05$. It can be said that those with high income consider that both bank syariah and conventional banks are the same. Third is legal status of banking interest. With coefficient $=1,606$. Sign positive means that the more the opinion on the unlawfulness of banking interest, the more they consider that Bank Syariah and conventional banks are different. Or, in other words, respondents who consider it unlawful will disagree on the opinion that Bank Syariah and conventional banks are the same. Sig $(p)=0,004<$ 0,05 . It can be said that the opinion on legal status of banking interest effect significantly on the attitude towards the opinion that bank syariah and conventional banks are the same.

c. First is education, with coefficient $=-0,069$ sign negative means that the higher the level of education they have, the more they consider that bank syariah is not in accordance with religious teaching. Or, in other words, the higher the level of education they have, the more they disagree on the opinion that the support to Bank Syariah is given because it is in accordance with religious teaching. Sig (p) 
$=0,9278>0,05$. It can be said that education does not effect on the attitude towards bank syariah as being in accordance with religious teaching. Second is income, with coefficient $=0,091$. Sign positive means that the higher the income they get, the higher their attitude that bank syariah is in accordance with religious teaching. But this attitude is not so significant. Sig $(p)=0,888>0,05$. It can be said that income does not effect on supporting attitude toward bank syariah as being in accordance with religious teaching. Third is legal status of banking interest. With coefficient $=1,171$. Sign positive means that the more they consider banking interest haram, the more the attitude towards bank syariah as being in accordance with religious teaching. Or, in other words, respondents who consider banking interest haram will agree if bank syariah is in accordance with religious teaching.

\section{F. Conclusion}

Many NU entrepreneurs in DIY are floating markets potential for the development of Bank Syariah. They believe that Bank Syariah is in accordance with Islamic teaching. They are familiar with Bank Syariah's products. But this is not a main factor which encourages them to choose Bank Syariah. Advantages, services, facilities, and nearness of branches are main factors which encourage them to change from conventional banks to bank syariah. Therefore, Bank Syariah should improve their services and interest of partnership better than interest system, and to open more branches.

\footnotetext{
* Financial staff of PSI-UII and teaching staff at Prodi Ekonomi Islam, FIAI-UII, Yogyakarta.

1 Syariah loyalists consider banking interest as riba and unlawful. See, "Perbankan Syariah Makin Diminati Masyarakat." Quoted from www.sinarharapan.co.id/ekonomi/ promarketing/2004/1009/prom1.html, accessed 28 September 2005.
} 
2 Floating market is market which is not committed to a certain banking system. It depends on the system which gives more profit. See, "Perbankan Syariah yang Semakin Memikat," dalam harian Kompas, 30 April 2003.

${ }^{3}$ Research conducted by Karim Business Consulting (KBC) from early 2004 by interviewing 21 directors of national banks shows that capital potency of loyalists is about $\mathrm{Rp} 10$ quintillion already invested to Bank Muamalat and Bank Syariah Mandiri. Lihat dalam "Perbankan Syariah Makin Diminati Masyarakat." In http://www.sinarharapan.co.id/ accessed 26 September 2005.

4 M Fajar Martha, "Saatnya Bank Syariah Garap Pasar Mengambang," dalam Kompas. Kamis, 07 Agustus 2003.

5 "Perbankan Syariah Makin...," in http://www.sinarharapan.co.id/ accessed 26 September 2005.

6 Bambang Tri Subeno, "Masa Depan Perbankan Syariah di Indonesia." In http://www.pesantrenonline.com/ berita/detailberita.php3?detail=2739 accessed 28 September 2005.

7 Sahal Mahfudz, "Bunga Bank Belum Jadi Fatwa MUI," dikutip dari http://www.suara merdeka.com. 21 December 200, accessed 29 November 2005.

8 Lajnah Bahsul Masail of the NU is an official forum which is responsible for answering all questions posed by members of the NU. See further, Ahmad Zahro, Lajnah Bahtsu al-Masâil Nahdlatul Ulama, Telaah Kritis Terhadap Keputusan Hukum Fiqih (Yogyakarta: Disertasi IAIN Sunan Kalijaga, 1999), p. 62.

9 Masdar F Masudi, "Soal Bunga Bank, Muhammadiyah dan NU Tidak Berubah", in http://www.tempointeraktif.com. 07 January 2004, accessed 29 November 2005.

10 Hadari Nawawi, Metode Penelitian Bidang Sosial, (Yogyakarta: UGM Press, 1995), p. 72.

11 Pengajian bisnis al-Kautsar is an independent organisation which is concerned with the economic development of the members of the NU through entrepreneurship. It was established by local officials of the NU DIY. Its members are about 229 enterpreneurs. See, Direktori Peluang Bisnis, (Yogyakarta: Pengajian Bisnis al-Kautsar, 2005), pp. 11-12

12 "Metodologi penelitian pengukuran (measurement) \& sampling," see http://yudhiher.files. wordpress.com/2007/04/transparansi-6-1.ppt, accessed 23 Mach 2007.

13 Saifuddin Azwar, Metode Penelitian, (Yogyakarta: Pustaka Pelajar, 1998), p. 101.

14 David HW and Lemeshow S, Applied Logistic Regression (New York: John Wileyang, 1989)

15 Zulaela, Modul Praktikum Analisis Data Kategorik (Yogyakarta: UGM, 2006), p55.

16 "Nahdlatu al-Tujjâr Sebagai Embrio NU," in http://www.nu.or.id/ page.php?lang=id\&menu=news_view\&news_id=144, 22 May 2003 18:00, accessed 17 December 2007.

17 Legal certificate of the establishment of Syirkah al-inan Murabitah Nahdatut Tujjar was signed on the end of Rajab 1336/1918.

18 Based on the certificate, its members were 45 persons from Jombang, Surabaya, Malang, Pasuruan, Bangil, on others. Each of them paid their initial share Rp.25,- for agricultural business.

19 Zul Asyi, Nahdlatul Ulama, Studi Tentang Faham Keagamaan dan Upaya Pelestariannya Melalui Lembaga Pendidikan Pesantren (Jakarta: Disertasi IAIN Syarif Hidayatullah, 1990) p. 68.

20 Jarkon Fatwa, Sekilas Nahd?lat?u al-Tujjâr (Yogyakarta: Pustaka Pesantren, 2004), p. 17.

21 Ibid, p. 20. 
22 In 1918 KH. Wahab Hasbullah, together with KH. Asnawi Kudus and KH. Abbas Jember, established the branch of Serikat Islam in Mecca. After his return, Wahab Hasbullah established Tashwirul Afkar in 1922 as a discussion forum. In this forum was involved KH.Mas Mansur of the Muhammadiyah. In 1926, Nahdhatul Watan was established, and at the same year, Nahdhatul Ulama was founded.

${ }^{23}$ See Abdul Muchit Muzadi, Mengenal Nahdlatul Ulama (Surabaya: Khalista, 2006), p.15.

${ }^{24}$ Rozy Munir, Nahdhatul Ulama dan Reorientasi Wawasan Ekonomi, dalam Muhammadiyah dan NU Reorientasi Wawasan Keislaman (Yogyakarta: kerjasama LPPI UMY, LKPSM Nudan PP.AlMuhsin, 1994), p. 137.

25 This forum organised its routine programmes ever month, by conducting tahlil (reciting la ilaha illa Allah) and discussion on religious and social matters. This forum was a response to economic depression in 1940 when small Muslim traders and farmers suffered from it.

26 Rozy Munir, Nahdhatul Ulama, pp. 138-140.

27 John L.Esposito, Ensiklopedi Oxford, Dunia Islam Modern (Bandung: Mizan, 2001), p148. Also see, "Perbankan II Gus Dur Membidik Ficor", in Gatra (No. 14/V, 20 February 1999). It is stated that in 1990, Abdurrahman Wahid, as the chairman of PB NU, made cooperation with Edward Soeryadjaya, the owner of Bank Summa, and Grup Jawa Pos, to found Bank Perkreditan Rakyat (BPR) Nusumma. At first, they successfully established twenty branches of BPR Nusumma and planned to establish 250 BPR in total. After Bank Summa was liquidated in 1992, NU and Jawa Pos took control of BPR.

28 A.Effendy Choirie, "Menyambut Harlah Ke-82 NU," dikutip dari http://gpansor.org/?p=4044, pada 2 Februari 2008, accessed 10 Februari 2008.

29 Statement of KH Suadi Mukhsin, tanfidyah PCNU Pasuruan, before Konferwil NU Jawa Timur, as quoted in Harian Bangsa, 29 October 2007.

30 Jamal Ma'mur Asmani, "Khittah NU Menjelang Pilpres II," dalam Suara Merdeka, (Rabu, 01 September 2004).

31 The statement of Hasyim Muzadi in the launch of Harian Koran Sindo Rabu, 21 November 2007, see 'PDT,MNC, dan PBNU Entaskan Kemiskinan' in http://www.lukmanedy.web.id/news/1/tahun/2007/bulan/11/tanggal/21/id/79/, accessed 16 December 2007

32 "Lembaga Perekonomian NU Yogya Bentuk Pengajian Bisnis "At-Tujjar"” quoted from http://www.nu.or.id/, accessed 13 May 2008.

33 Direktori Peluang Bisnis (Yogyakarta: Pengajian Bisnis al-Kautsar, 2005), pp. 11-12.

34 Abdul Djalil Khamid Kudus, Ahkâm al-Fuqahâ fi Muqarrarât Mu'tamarât Nahdatul 'Ulama, Kumpulan Masalah-masalah Diniyah dalam Muktamar NU, Juz I, (Semarang: Toha Putra, n.d), pp. 22-23.

35 Jalaluddin As-Suyûtiy, (tt), al-Asybâh wa an-Nazâir fi al-Furû', (Dâhyâ' al Kutub al'Arabiyyah, tt), hal 67; Abu Bakr Usman Bin Muhammad Syattâ al-Bakriy, Hâsyiyah I'ânah atTalibîn, juz III, (Beirut: Dâr al-Kutub al-'Ilmiyyah, 1995), p. 56.

36 Ahmad Abdul Hamid Kendal, Putusan Kongres Jamiyyah Nahdlatul Ulama Kaping 12 (Kudus: TBS Koedoes, 1938), p. 16.

37 H.B.N.O., Verslag-Congres Nahdlatoel Oelama' jang ke-14 (Soerabaya: H.B.N.O., 1939), pp. 23-25. 
38 Azis Masyhuri, Masalah Keagamaan Nahdlatul Ulama (Surabaya: PP RMI dan Dinamika Press, 1997), pp. 212-214.

39 Abu Bakr Usman, Hâsyiyah I'ânah, p. 20.

40 Al-Haitamiy, Tuhfah al-Muhtaj, vo. 2, p24.

41 Azis Masyhuri, Masalah, p. 250.

42 Panitia Penyelenggara Munas dan Konbes NU, Keputusan Munas Alim Ulama NU 1987, (Jakarta: Panitia Penyelenggara Munas dan Konbes, tt).

43 According to Kumala Hadi, Vice-President of PW-NU DIY, current Bank Syariah are in fact just like usurers, since high percentage of (shared) interest is taken.

44 Some respondents told that products of Bank Syariah are weightier for customers. 


\section{BIBLIOGRAPHY}

al-Bakriy, Abu Bakr Usman Bin Muhammad Syattâ. 1995. Hâsyiyah I'ânah atTalibîn. juz III. Beirut: Dâr al-Kutub al-'Ilmiyyah.

Asmani, Jamal Ma'mur. 2004. "Khittah NU Menjelang Pilpres II”, in Suara Merdeka, Wednesday, 1 September 2004.

As-Suyûtiy, Jalaluddin. tt. al-Asybâh wa an-Nazâir fi al-Furû', Dâhyâ' al Kutub al'Arabiyyah.

Asyi, Zul. 1990. "Nahdlatul Ulama, Studi Tentang Faham Keagamaan dan Upaya Pelestariannya Melalui Lembaga Pendidikan Pesantren”. Jakarta: Dissertation at IAIN Syarif Hidayatullah.

Azwar, Saifuddin. 1998. Metode Penelitian. Yogyakarta: Pustaka Pelajar.

Choirie, A.Effendy, "Menyambut Harlah Ke-82 NU," on http://gpansor.org/?p=4044.

David HW and Lemeshow S. 1989. Applied Logistic Regression. New York: John Wileyang Sons, Inc.

Esposito, John L. 2001. Ensiklopedi Oxford, Dunia Islam Modern, Bandung: Mizan.

Fatwa, Jarkon. 2004. Sekilas Nahd?lat?u al-Tujjâr, Yogyakarta: Pustaka Pesantren.

H.B.N.O. 1939. Verslag-Congres Nahdlatoel Oelama' jang ke-14, Soerabaya: H.B. N.O.

Kendal, Ahmad Abdul Hamid. 1938. Putusan Kongres Jamiyyah Nahdlatul Ulama Kaping 12, Kudus: TBS Koedus.

Kotler, Philip. 1997. Marketing Management: Analysis, Planning, Implementation, and Control, Ninth Edition, New York: Prentice-Hall.

Kudus, Abdul Djalil Khamid. tt. Ahkâm al-Fuqahâ fi Muqarrarât Mu'tamarât Nahdatul 'Ulama, Kumpulan Masalah-masalah Diniyah dalam Muktamar NU, Juz I, Semarang: Toha Putra.

"Lembaga Perekonomian NU Yogya Bentuk Pengajian Bisnis 'At-Tujjar", on http://www.nu.or.id.

Mahfudz, Sahal. 2003. "Bunga Bank Belum Jadi Fatwa MUI" on http://www.suaramerdeka.com.

Martha, M Fajar. 2003. "Saatnya Bank Syariah Garap Pasar Mengambang," in Kompas, Thursday, 07 August 2003.

Masudi, Masdar F,. 2004. "Soal Bunga Bank, Muhammadiyah dan NU Tidak Berubah," on http://www.tempointeraktif.com. 
Masyhuri, Azis. 1997. Masalah Keagamaan Nahdlatul Ulama, Surabaya: PP RMI dan Dinamika Press.

"Metodologi penelitian pengukuran (measurement) \& sampling," on http://yudhiher.files. wordpress.com/.

Munir, Rozy. 1994. "Nahdhatul Ulama dan Reorientasi Wawasan Ekonomi," in Muhammadiyah dan NU Reorientasi Wawasan Keislaman, Yunahar Ilyas et. al. (ed.), Yogyakarta: LPPI UMY, LKPSM NU and PP.Al-Muhsin.

Muzadi, Abdul Muchit. 2006. Mengenal Nahdlatul Ulama. Surabaya: Khalista.

Muzadi, Hasyim, 'PDT,MNC, dan PBNU Entaskan Kemiskinan' on http://www.lukman-edy.web.id/.

"Nahdlatu al-Tujjâr Sebagai Embrio NU," on http://www.nu.or.id/ page.php?lang=id\&menu=news_view\&news_id=144.

Nawawi, Hadari. 1995. Metode Penelitian Bidang Sosial. Yogyakarta: Gajah Mada University Press.

"Perbankan II Gus Dur Membidik Ficor" in Gatra Nomor 14/V, 20 February 1999.

"Perbankan Syariah Makin Diminati Masyarakat," on www.sinarharapan.co.id/ekonomi/promarketing/2004/1009/prom1.html.

Perbankan Syariah yang Semakin Memikat, in Kompas, 30 April 2003.

Subeno, Bambang Tri, "Masa Depan Perbankan Syariah di Indonesia" (2-Habis), on http://www.pesantrenonline.com/.

Zahro, Ahmad. 1999. Lajnah bahsÿu al-Masâil Nahdlatul Ulama, Telaah Kritis Terhadap Keputusan Hukum Fiqih. Yogyakarta: Dissertation at IAIN Sunan Kalijaga.

Zulaela. 2006. Modul Praktikum Analisis Data Kategorik. Yogyakarta: UGM. 